\title{
An assessment of awareness of mental health conditions and its association with socio-demographic characteristics: a cross- sectional study in a rural district in Bangladesh
}

Mohammed Nazim Uddin ${ }^{1 *}$, Sunil Bhar ${ }^{2}$ and Fakir M Amirul Islam ${ }^{1,3}$

\begin{abstract}
Background: To assess the level of awareness, knowledge and help-seeking attitudes and behaviours in relation to mental health conditions (MHCs) and associations with socio-demographic characteristics of a rural district of Bangladesh.

Methods: We recruited 2425 adult samples (18-90 years) from a Cross-sectional study in Narial district of Bangladesh. Data on awareness, knowledge, help-seeking attitudes and practice in relation to six MHCs were collected. The MHCs were classified as common (depression, anxiety and drug addiction), and severe (psychosis, dementia and bipolar disorder). Associations of MHCs with socio-demographic characteristics were assessed using Chi-square tests. Rasch analysis was performed to transform the latent attribute (awareness) of MHCs from ordinal to interval scale. Multiple regression analysis was performed to determine how the socio-demographic characteristics contribute to the combined awareness score of MHCs.
\end{abstract}

Results: Of 2425 participants, 17 (0.7\%) were cognizant of all the awareness construct of MHCs, and 1365 (56.28\%) were not aware of any of MHCs. The prevalence of awareness of MHCs such as depression (8.5\%), anxiety (6.2\%), psychosis (3.5\%), and bipolar disorder (3.3\%), was found to be very low. Awareness was significantly lower in older adults, and in women. Higher levels of education ( $\beta$ 1.77, 95\% confidence interval (Cl): 1.58-1.97) associated with common MHCs and ( $\beta$ 0.81, 95\% Cl: 0.67-0.95) those associated with severe MHCs contributed significantly to increased awareness as opposed to having no or primary level of education. Availability of sufficient funds when applied to common MHCs ( $\beta$ 0.43, 95\% Cl: 0.26-0.61) and severe MHCs ( $\beta$ 0.25, 95\% Cl: 0.13-0.38) appeared to be more effective in boosting awareness compared to unstable financial situations. Almost $100 \%$ of the participants who were aware of the MHCs demonstrated positive attitudes towards seeking medical or psychological counselling.

\footnotetext{
* Correspondence: mnuddin@swin.edu.au

'Department of Statistics, Data Science and Epidemiology; Faculty of Health,

Arts and Design, Swinburne University of Technology, Hawthorn, VIC 3122,

Australia

Full list of author information is available at the end of the article
}

(c) The Author(s). 2019 Open Access This article is distributed under the terms of the Creative Commons Attribution 4.0 International License (http://creativecommons.org/licenses/by/4.0/), which permits unrestricted use, distribution, and reproduction in any medium, provided you give appropriate credit to the original author(s) and the source, provide a link to the Creative Commons license, and indicate if changes were made. The Creative Commons Public Domain Dedication waiver (http://creativecommons.org/publicdomain/zero/1.0/) applies to the data made available in this article, unless otherwise stated. 
(Continued from previous page)

Conclusions: Awareness of MHCs appeared to be very limited. However, knowledgeable participants were found to be very receptive to medical or psychological counselling. For improving awareness of MHCs need to conduct various intervention programs in particular those campaigns that focus on women, older adults, low SES and people up to the primary levels of education.

Keywords: Mental health conditions, Knowledge attitude and practice, Rasch analysis, Rural Bangladesh, Mental health literacy,

\section{Background}

Approximately $7.3 \%$ of the global burden of disease has been attributed to mental and behavioural disorders. Most of this burden is related to unipolar depressive disorders and other mental health conditions (MHCs) including anxiety, psychosis and substance use [1]. Currently, approximately 450 million people suffer from such conditions, and it is projected that one in four individuals in the world will be affected by MHCs at some point in their lifetimes. MHCs are amongst the leading causes of ill-health and disability worldwide [2]. Globally, approximately $20 \%$ of the adults have MHCs, and low and middle-income countries have only one psychiatrist for every 1 to 4 million people [3, 4]. People with MHCs experience disproportionately higher rates of disability and mortality [5]. Individuals with major depressive disorders and schizophrenia had 40 to $60 \%$ greater chance of dying prematurely than the general population [6].

Mental health literacy (MHL), defined as "knowledge and attitudes about MHCs which aid their recognition, management and prevention" is low worldwide, but specifically low in developing countries [7]. In such societies, MHCs are believed to be consequences of familial imperfection and evil spirits [8]. Such beliefs have been purported to lead to poor utilisation and negative stigma about mental health services and treatment [9]. Unsurprisingly, poor health literacy is associated with negative disease outcomes, especially in developing countries [10-13].

The importance of health literacy on physical health is widely acknowledged in the world [14]. However, the literacy about MHCs has been neglected in both developed and developing countries [15]. The common myths in developing and developed countries are that the MHCs are not curable, caused by personal weakness, and that people with MHCs are usually violent or unstable [16]. A study from Germany reported that people were more reluctant to discuss MHCs than physical disorders with relatives and friends [17]. In the USA, many public servants did not seek treatments because they feared that MHCs would create the negative impact on their employment [18]. In developing countries, utilising services for MHCs are further blocked by stigma and beliefs about MHCs being due to sorcery or spiritual punishment, possessions by spirits and demons, genetic or family inheritance, social or moral disobediences towards ancestors or wraths of Gods [19]. A study from Nigeria showed that women in the community would be afraid to have a conversation with someone known to have mental disorders [20]. In the United Arab Emirates (UAE), women were ashamed to mention that they had a family member with mental illness, but this attitude was lower in men [21]. Moreover, a study from India reported that women thought that MHCs were family matters and should not be disclosed to other people [22]. However, in developing countries including Bangladesh and India, visiting a traditional healer for emotional problems was more common in women than in men [23]. A study revealed that in Qatar men possessed better knowledge, beliefs, and attitudes towards mental illness than women [21].

Despite the association between MHL and diseases outcomes, levels of MHL in rural regions of Bangladesh are unknown. Studies are needed to understand the level of MHL in the population and to develop targeted programs to address such levels. In the last decade, several studies have reported the prevalence of and contributing factors for depression and anxiety both in urban and rural areas in Bangladesh [24-32]. However, no study has assessed awareness, knowledge, and attitudes of seeking medical treatment regarding MHCs in Bangladesh. Rural areas in Bangladesh are characterised by traditional healing practices and an absence of mental health facilities and care. Therefore, studies on MHL are imperative to gauge and increase the level of awareness of MHCs in rural populations in Bangladesh.

The current study had two aims. First, it aimed to estimate the level of MHL in a typical rural district of Bangladesh. Second, it aimed to identify socio-demographic characteristics associated with MHL in order to identify the factors that affect rural communities and therefore inform potential interventions for improving MHL.

\section{Methods}

Study sample

Bangladesh is a country of 163 million people divided into 64 districts. Participants were recruited from the 
Narail district, which is located approximately $200 \mathrm{~km}$ south-west of Dhaka, the capital city of Bangladesh. The population of Narail district is 272,872 , with approximately $40 \%$ of residents aged between 18 and 59 years and 19,000 (about 7\%) of residents aged between 60 and 90 years. The study location was selected as it was reflective of typical rural demography in Bangladesh. The Narail district with an estimated population density of 722 people was comparable to the national rural population density of 873 people per square kilometre. Narail is not at the extremity of remote locations nor is it a catchment of a metropolis such as Dhaka [33]. The area of Narail is $381.76 \mathrm{~km} 2$, located in between $23^{\circ} 02^{\prime}$ and $23^{\circ} 17^{\prime}$ north latitudes and in between $89^{\circ} 23^{\prime}$ and $89^{\circ} 37^{\prime}$ east longitudes. The district is surrounded by Lohagara and Salikha upazilas on the north, Kalia and Abhaynagar upazilas on the south, Lohagara upazila on the east, and Bagherpara and Jessore Sadar upazilas on the west. The ratio of male to female (48.5 to 51.5) resembled quite well with that of Bangladesh (48.9 to 51.1) [34]. 72.3\% of sample data attained primary education or above as opposed to $72.9 \%$ [35] of the national population, while $27.7 \%$ of it had no education, which was comparable to the national $27.1 \%$ [35]. In the make-up of the population with respect to marital status, the Married group of Narial sample data $(79.9 \%)$ was fairly proximate to the national level (80.01\%) [36]. With respect to the availability of funds, a determinant for socio-economic condition, the sample population having insufficient funds some / most of the time accounted for 32.2 and $23.2 \%$ [37] in Bangladesh. In summary, the socio-demographic make-up of the Narail district delineated well the typical characteristics of a rural district of Bangladesh. Moreover, researchers carried out studies [32, 38, 39] in Narail district earlier and motived to advance further studies based on the population of Narail district.

\section{Sample size and statistical power}

The sample comprised 2425 participants, aged between 18 to 90 years from the Narail district. The sample including 1147 older adults and 1278 adults. Prior data indicate that the prevalence of severe depression was $21 \%$ in older adults aged 60 years or above, and $6.5 \%$ in adults aged between 18 and 60 years [40]. We assumed a margin of error of $5 \%$ in prevalence rates for older adults, and of $3 \%$ for adults when estimating the true prevalence of severe depression for each cohort in this rural area [40]. Using a significance level of 0.05 and statistical power above $80 \%$, a required sample size of 1128 was needed for the older adult cohort and 1283 for the adult group.

The sample size of 2425 was sufficiently large enough to detect a minimum 5\% difference in proportion of attaining awareness or knowledge of MHCs related items between men and women; no schooling and primary or secondary level of education; have sufficient funds most of the time and insufficient funds some of the time (statistical power $90 \%, p=0.05$ ).

\section{Sampling frame}

A multi-stage cluster random sampling technique was used for this study. Three unions from a total of 13 and one ward from a total of 9 wards of Narail upazilla were randomly selected at level 1 . Two to three villages or mohalla from each selected union or ward were randomly selected at the level 2. About 120 older adults and 150 adults were interviewed from each of the villages. Recruitment strategy and quality assurance in data collection were described in details previously [38]. In brief, all team members participated in an intensive 2day training programme in Narail before the commencement of the survey. The purpose of the training was to outline the rationale of the study, and the procedures and potential difficulties associated with data collection. The interviewers were instructed to visit every household within the randomly selected villages and to interview one household member of an older adult first. If none were available in this subgroup, the interviewers were approached an adult person of that household. If there was more than one male or female adult in the same household, one individual was selected, based on who was born closer to January. However, to maintain an approximately equal number of males and female participants, one female was interviewed immediately after a male participant. The recruitment started from a corner of a village and continued until the recruitment of a maximum of 250 participants was reached for a large village where the number of eligible participants were greater than 250 . In case of fewer than 250 households in a village, the requirement continued to the adjacent village to reach the number to 250 .

\section{MHCs measures}

Given the relative lack of validated MHL data, the specific items measuring MHL were sourced from the National Survey of Mental Health Literacy and Stigma in Australia [41]. A questionnaire comprising these items assessed participants' awareness of six MHCs (depression, bipolar disorder, anxiety, psychosis, dementia, and drug addiction) by asking if they had ever heard of these conditions with a possible response of "yes" or "no". Based on their responses, they were asked to list at least one symptom of these conditions, this provided insight into the level of knowledge they possessed. Attitudes towards the use of treatment was assessed by asking the question "do they or their relatives need treatment?" with a possible response of "yes" or "no". Participants were also asked if they or their relatives had ever 
experienced any MHCs, and if so, if they had undertaken treatment from a "medical doctor", "psychologist" or others such as "spiritual persons".

\section{Outcome variables}

The outcome variables were determined by the level of awareness of MHCs divided into two groups, common (depression, anxiety and drug addiction) and severe (psychosis, dementia, and bipolar disorder) MHCs. Knowledge was measured based on whether the participants could identify at least one symptoms of the MHCs given that they were aware of the conditions. Attitudes were defined as positive if the participants who were aware of the MHCs were in favour of taking medical treatment or psychological counselling. Practice was defined based on whether participants' themselves or their relatives with MHCs had undertaken medical treatment or psychological counselling.

\section{Socio-demographic covariates}

Demographic details for age was categorised into adult (18 to 59 years) and older adult (60 to 90 years) groups. Level of education was categorised into five categories: no schooling, primary school level of education (grade 1 to 5), secondary school level of education (grade 6 to 10), school secondary certificate (SSC) or higher secondary certificate (HSC), bachelor's degree or above. SES was assessed according to Cheng et al. [42] asking whether "over the last twelve months, concerning household food consumption, how would you classify your socioeconomic status?" The possible answers were: (i) insufficient funds for the whole year; (ii) insufficient funds some of the time; (iii) neither a deficit nor surplus (balance); and (iv) sufficient funds most of the time. Occupation was categorised as students, housewives, landowners, labourers, business men or women, government or non-government employees and retired persons.

\section{Statistical analyses}

Participant's sociodemographic characteristics including age, gender, level of education, occupation and SES were reported using descriptive statistics. Association of MHCs with gender, levels of education and other categorical factors were evaluated using Chi-square tests. The linear-by-linear association option in Chi-square test was used to report trends for ordinal categorical variables. Rasch Analysis is a unique approach of mathematical modelling based upon a latent trait and accomplishes stochastic (probabilistic) conjoint additivity (conjoint means measurement of persons and items on the same scale and additivity is the equal-interval property of the scale) [43]. Rasch models are used when a set of questionnaire items are intended to be summed together to provide a total score. In this study, Rasch analysis [44] was performed to compute the person measures based on the awareness for common and severe MHCs on a logarithmic scale and termed as "awareness score". The negative value of an awareness score indicates the person has below average awareness, zero value indicates average and positive value indicates above average level of awareness of the items. Differentials of the measures of awareness and help-seeking attitudes and behaviour in relation to MHCs were evaluated across different major categories of age, gender, the level of education and other socioeconomic factors using Pearson Chi-square tests of independence. Multiple regression analysis techniques were used to evaluate the direction and strength of the effects of socio-economic factors gender, age, SES and education in predicting awareness of underlying MHCs. Data were analysed using RUMM2030 [45] and SPSS 24.0 [46].

\section{Results}

Mean (SD, range) age of the participants was 52.0 years (17, 18-90). The demographic makeup of the total participants was $48.5 \%$ men and $51.5 \%$ women. As to the educational attainment, a considerably large proportion $(66.6 \%)$ of population's highest level of education was very modest, where $27.6 \%$ did not have any formal education and 39\% completed primary education. About 14 and $16 \%$ of participants earned secondary and SSC/HSC degree respectively, while only $4 \%$ had their highest level of degree bachelor or above. The disparity between the educational distribution of adults and older adults is evident from the fact that older adults have relatively more percentage of people without education and less percentage of people with secondary education or higher as opposed to the adults. Socio-economic condition of the participants reflected that majority (about 52.9\%) of them had financial stability ( $43 \%$ accounting for balance and $9.9 \%$ accounting for sufficient funds most of the time), while $32.2 \%$ reported occasional instability and $15.1 \%$ had precarious financial situations. Two major occupations in the overall participants were homemakers (40\%) and retired persons (22.1\%). Overall 5.6\% were engaged in government or non-government employment, comprised of $7.6 \%$ in the adults age group and 3.5\% older adults age group. Majority of the participants were married, and the second largest matrimonial class was widow with differential proportions in adults (3\%) and older adults (32\%). The socio-demographic characteristics of the participants by two age groups (adults and older adults) are shown in (Table 1).

Overall, perceived awareness of MHCs was low ranging from 3.3\% (bipolar disorder) to $42 \%$ (drug addiction). Adults were more aware of most of the MHCs than the older adults (for example, drug addiction: $52.0 \%$ of adults vs. $30.8 \%$ of older adults, dementia 
Table 1 Sociodemographic characteristic of adults and elderly in Narail district in Bangladesh

\begin{tabular}{|c|c|c|c|}
\hline \multirow[t]{2}{*}{ Characteristic } & Total (2425) & Adults, $n=1278$ (52.7\%) & Older adults, $n=1147$ (47.3\%) \\
\hline & Mean (SD) & Mean (SD) & Mean (SD) \\
\hline Age (in years) & $52(17.0)$ & $38(9.0)$ & $67(7.4)$ \\
\hline Gender & Number (\%) & Number (\%) & Number (\%) \\
\hline Female & $1249(51.5)$ & $675(52.8)$ & $574(50.0)$ \\
\hline Male & $1176(48.5)$ & $603(47.2)$ & $573(50.0)$ \\
\hline \multicolumn{4}{|l|}{ Level of education (in years) } \\
\hline No education & $671(27.7)$ & $171(13.4)$ & $500(43.6)$ \\
\hline Primary (1-5) & $946(39.0)$ & $510(39.9)$ & $436(38.0)$ \\
\hline Secondary (6-9) & $327(13.4)$ & 238 (18.6) & $89(7.8)$ \\
\hline SSC or HSC Pass (10-12) & $385(15.9)$ & $295(23.1)$ & $90(7.8)$ \\
\hline Degree or equivalent (13-16) & $96(4.0)$ & $64(5.0)$ & $32(2.8)$ \\
\hline \multicolumn{4}{|l|}{ Socio-economic condition: } \\
\hline Insufficient funds most of the time & $367(15.1)$ & $172(13.5)$ & $195(17.0)$ \\
\hline Insufficient funds some of the time & $781(32.2)$ & $400(31.3)$ & $381(33.2)$ \\
\hline Balance & $1037(42.8)$ & $582(45.5)$ & $455(39.7)$ \\
\hline Sufficient funds most of the time & $240(9.9)$ & $124(9.7)$ & $116(10.1)$ \\
\hline \multicolumn{4}{|l|}{ Occupation } \\
\hline Student & $45(1.9)$ & $40(3.1)$ & $5(0.4)$ \\
\hline Housewives & $970(40.0)$ & $629(49.2)$ & $341(29.7)$ \\
\hline Land owner & $217(8.9)$ & $130(10.2)$ & $87(7.6)$ \\
\hline Labourers & $297(12.2)$ & $206(16.1)$ & $91(7.9)$ \\
\hline Business & $222(9.2)$ & $165(12.9)$ & $57(5.0)$ \\
\hline Government or non-government employee & $137(5.6)$ & $97(7.6)$ & $40(3.5)$ \\
\hline Retired & $537(22.1)$ & $11(0.9)$ & $526(46)$ \\
\hline \multicolumn{4}{|l|}{ Marital status } \\
\hline Married & $1937(79.9)$ & $1163(91.0)$ & $774(67.5)$ \\
\hline Widow & $405(16.7)$ & $38(3.0)$ & $367(32.0)$ \\
\hline Unmarried/never married & $78(3.2)$ & $73(5.7)$ & $5(0.4)$ \\
\hline Divorced/separated & $5(0.2)$ & $4(0.3)$ & $1(0.1)$ \\
\hline
\end{tabular}

disorder: $33.1 \%$ of adults vs. $20.8 \%$ of older adults), which is also evident from the significant associations of age groups and MHCs. Of participants who were aware of MHCs, more than about $90 \%$ were able to identify at least one symptom with slightly lower than $80 \%$ being cognizant of bipolar disorder symptom.

Almost all the participants were in favour of treating the MHCs. Although awareness of MHCs appeared to be associated with age groups, knowledge and attitude did not exhibit any impact of age. For instance, the proportion of positive attitude towards treating depression was $99 \%$ and did not vary significantly across the two age groups (adults and older adults Table 2).

Of the total participants $42.5 \%$ (38.0\% of women vs. $47.2 \%$ of men, $p<0.001$ ) were aware of any common MHCs, while $3.4 \%$ were aware of all three common MHCs. However, only $28.1 \%$ were aware of any severe
MHCs while $1.3 \%$ were aware of all three severe MHCs. Among those who were aware of at least one MHCs, only $9(0.9 \%)$ and $6(0.9 \%)$ participants, reported that they had suffered common and severe MHCs respectively (Table 3). Awareness of any common MHCs was significantly higher in males compared to females and a similar pattern was observed in both underlying age groups for both common and severe MHCs (Fig. 1). Higher level of education (e.g.,73\% of people with at least bachelor's degree were aware of depression compared to $1 \%$ of people with no or primary level of education) and better SES appeared to be associated with higher prevalence of awareness of all the MHCs except anxiety (Table 4).

The awareness scores obtained from Rasch analysis were categorised into two groups: persons having awareness scores greater than or equal to zero were 
Table 2 Level of awareness and knowledge of MHCs, and attitudes towards treatments for mental well-being by different MHCs and age groups in Narail district in Bangladesh

\begin{tabular}{|c|c|c|c|c|c|c|c|c|c|c|}
\hline \multirow{4}{*}{$\begin{array}{l}\text { Mental } \\
\text { Health } \\
\text { Conditions }\end{array}$} & \multirow{4}{*}{$\begin{array}{l}\text { Awareness } \\
\text { (heard of) }\end{array}$} & \multirow{4}{*}{$\begin{array}{l}\text { Awareness } \\
n=2425 \\
n(\%)\end{array}$} & \multicolumn{2}{|c|}{ Total participants } & \multicolumn{6}{|c|}{ Adults and Older Adults } \\
\hline & & & \multirow{3}{*}{$\begin{array}{l}\text { Knowledge }^{\mathrm{b}} \\
\mathrm{n}(\%)\end{array}$} & \multirow{3}{*}{$\begin{array}{l}\text { Attitude towards } \\
\text { treatment } \\
\mathrm{n}(\%)\end{array}$} & \multicolumn{2}{|c|}{ Awareness } & \multicolumn{2}{|c|}{ Knowledge $^{\mathrm{b}}$} & \multicolumn{2}{|c|}{$\begin{array}{l}\text { Attitude towards } \\
\text { treatment }{ }^{b}\end{array}$} \\
\hline & & & & & $\begin{array}{l}\text { Adults, } n= \\
1278\end{array}$ & $\begin{array}{l}\text { Older Adults } \\
n=1147\end{array}$ & Adults & $\begin{array}{l}\text { Older } \\
\text { Adults }\end{array}$ & Adults & $\begin{array}{l}\text { Older } \\
\text { Adults }\end{array}$ \\
\hline & & & & & n (\%) & n (\%) & n (\%) & n (\%) & n (\%) & n (\%) \\
\hline \multirow[t]{3}{*}{$\begin{array}{l}\text { Common } \\
\text { MHCs }\end{array}$} & Depression & $206(8.5)$ & 199 (96.6) & $204(99.0)$ & $149(11.7)$ & $57(5.0)^{a}$ & $\begin{array}{l}143 \\
(96.0)\end{array}$ & $56(98.2)$ & $\begin{array}{l}148 \\
(99.3)\end{array}$ & $56(98.2)$ \\
\hline & Anxiety & $151(6.2)$ & $141(93.4)$ & $149(98.7)$ & $121(9.5)$ & $30(2.6)^{\mathrm{a}}$ & $\begin{array}{l}113 \\
(93.4)\end{array}$ & $28(93.3)$ & $\begin{array}{l}119 \\
(98.3)\end{array}$ & $30(100)$ \\
\hline & $\begin{array}{l}\text { Drug } \\
\text { addiction }\end{array}$ & $\begin{array}{l}1018 \\
(42.0)\end{array}$ & $1006(99.0)$ & 1004 (99) & $665(52.0)$ & $353(30.8)^{a}$ & $\begin{array}{l}659 \\
(99.0)\end{array}$ & 347 (98.0) & $\begin{array}{l}652 \\
(98.0)\end{array}$ & $352(100)$ \\
\hline \multirow[t]{3}{*}{$\begin{array}{l}\text { Severe } \\
\text { MHCs }\end{array}$} & Psychosis & $85(3.5)$ & $76(89.4)$ & $85(100)$ & $60(4.7)$ & $25(2.2)^{\mathrm{a}}$ & $\begin{array}{l}53 \\
(88.3)\end{array}$ & $23(92.0)$ & $\begin{array}{l}60 \\
(100)\end{array}$ & $25(100)$ \\
\hline & Dementia & $662(27.3)$ & $659(99.5)$ & $661(99.8)$ & $423(33.1)$ & $239(20.8)^{a}$ & $\begin{array}{l}421 \\
(99.5)\end{array}$ & 238 (99.6) & $\begin{array}{l}422 \\
(99.8)\end{array}$ & $239(100)$ \\
\hline & $\begin{array}{l}\text { Bipolar } \\
\text { disorder }\end{array}$ & $79(3.3)$ & $63(79.7)$ & $78(98.7)$ & $59(4.6)$ & $20(1.7)^{\mathrm{a}}$ & $\begin{array}{l}46 \\
(78.0)\end{array}$ & $17(85.0)$ & $\begin{array}{l}58 \\
(98.3)\end{array}$ & $20(100)$ \\
\hline
\end{tabular}

${ }^{\mathrm{a}}$ Significant at $0.001 ;{ }^{\mathrm{b}}$ knowledge is related to participants who are aware about the disorders

considered to possess 'average or above level of awareness', and scores lower than zero were deemed to possess 'below average level of awareness'. The mean (95\% CI) awareness score of common MHCs was -4.29 (-4.38, $4.19)$, and for severe MHCs was $-2.18(-2.25,-2.12)$, indicating that, participants had a below average level of awareness. Only $82(3.4 \%)$ and $113(4.7 \%)$ participants had an awareness score above zero for common and severe awareness of MHCs respectively. Overall, this indicates they had an above average level of awareness. People who had bachelor's or higher level of education were the sole group to have an above average awareness score for severe MHCs (multivariate adjusted mean (95\% CI) score, $0.32(0.04,0.61))$ (Additional file 1).

Multiple regression analysis was performed where person measure was considered as the dependent variable and gender, age, SES, education as independent variables. After controlling the effects of age, SES and level

Table 3 Level of awareness of MHCs by gender and age groups (adults, older adults) and their associations in Narail district in Bangladesh

\begin{tabular}{|c|c|c|c|c|c|c|c|c|c|c|}
\hline \multirow{3}{*}{$\begin{array}{l}\text { Mental } \\
\text { Health } \\
\text { Conditions }\end{array}$} & \multirow[t]{3}{*}{ Awareness, (heard of) } & \multicolumn{3}{|c|}{ Total, $n=2425$} & \multicolumn{3}{|c|}{ Adults, $n=1278$} & \multicolumn{3}{|c|}{ Older adults, $n=1147$} \\
\hline & & Total & $\begin{array}{l}\text { Female, } n= \\
1249\end{array}$ & $\begin{array}{l}\text { Male, } n= \\
1176\end{array}$ & Total & $\begin{array}{l}\text { Female, } \\
n=675\end{array}$ & $\begin{array}{l}\text { Male, } n= \\
603\end{array}$ & Total & $\begin{array}{l}\text { Female, } \\
n=574\end{array}$ & $\begin{array}{l}\text { Male, } n= \\
573\end{array}$ \\
\hline & & n (\%) & n (\%) & n (\%) & n (\%) & n (\%) & n (\%) & n (\%) & n (\%) & n (\%) \\
\hline \multirow[t]{5}{*}{$\begin{array}{l}\text { Common } \\
\text { MHCs }\end{array}$} & Awareness of any MHCs & $\begin{array}{l}1030 \\
(42.5)\end{array}$ & $475(38.0)$ & $555(47.2)^{a}$ & $\begin{array}{l}672 \\
(52.6)\end{array}$ & $321(47.6)$ & $\begin{array}{l}351 \\
(58.2)^{a}\end{array}$ & $\begin{array}{l}358 \\
(31.2)\end{array}$ & $154(26.8)$ & $\begin{array}{l}204 \\
(35.6)^{a}\end{array}$ \\
\hline & $\begin{array}{l}\text { Knowledge of any } \mathrm{MHCs}^{\mathrm{b}} \\
\text { symptom }\end{array}$ & $\begin{array}{l}1020 \\
(99)\end{array}$ & $470(98.9)$ & $550(99.1)$ & $\begin{array}{l}667 \\
(99.3)\end{array}$ & $318(99.1)$ & $349(99.4)$ & $\begin{array}{l}353 \\
(98.6)\end{array}$ & $152(98.7)$ & $201(98.5)$ \\
\hline & Awareness of all MHCs & $82(3.4)$ & $28(2.2)$ & $54(4.6)^{a}$ & $64(5)$ & $26(3.9)$ & $38(6.3)^{a}$ & $18(1.6)$ & $2(0.3)$ & $16(2.8)^{a}$ \\
\hline & $\begin{array}{l}\text { Knowledge of all MHCs } \\
\text { symptoms }\end{array}$ & $\begin{array}{l}76 \\
(92.7)\end{array}$ & $24(85.7)$ & $52(96.3)$ & $\begin{array}{l}58 \\
(90.6)\end{array}$ & $22(84.6)$ & $36(94.7)$ & $\begin{array}{l}18 \\
(100)\end{array}$ & $2(100)$ & $16(100)$ \\
\hline & Self-reported MHCs & $9(0.9)$ & $5(1.1)$ & $4(0.7)$ & $7(1)$ & $4(1.2)$ & $3(0.9)$ & $2(0.6)$ & $1(0.6)$ & $1(0.5)$ \\
\hline \multirow[t]{5}{*}{ Severe MHCs } & Awareness of any MHCs & $\begin{array}{l}682 \\
(28.1)\end{array}$ & $334(26.7)$ & $348(29.6)$ & $\begin{array}{l}438 \\
(34.3)\end{array}$ & $217(32.1)$ & $221(36.7)$ & $\begin{array}{l}244 \\
(21.3)\end{array}$ & $117(20.4)$ & $127(22.2)$ \\
\hline & $\begin{array}{l}\text { Knowledge of any MHCs } \\
\text { symptom }\end{array}$ & $\begin{array}{l}676 \\
(99.1)\end{array}$ & $331(99.1)$ & $345(99.1)$ & $\begin{array}{l}433 \\
(98.9)\end{array}$ & $215(99.1)$ & $218(98.6)$ & $\begin{array}{l}243 \\
(99.6)\end{array}$ & $116(99.1)$ & $127(100)$ \\
\hline & Awareness of all MHCs & $31(1.3)$ & $13(1.0)$ & $18(1.5)$ & $24(1.9)$ & $12(1.8)$ & $12(2)$ & $7(0.6)$ & $1(0.2)$ & $6(1.0)$ \\
\hline & $\begin{array}{l}\text { Knowledge of all } \mathrm{MHCs}^{\mathrm{b}} \\
\text { symptoms }\end{array}$ & $\begin{array}{l}23 \\
(74.2)\end{array}$ & $8(61.5)$ & $15(83.3)$ & $\begin{array}{l}17 \\
(70.8)\end{array}$ & $8(66.7)$ & $9(75)$ & $6(85.7)$ & $0(0)$ & $6(100)$ \\
\hline & Self-reported MHCs & $6(0.9)$ & $3(0.9)$ & $3(0.9)$ & $4(0.9)$ & $1(0.5)$ & $3(1.4)$ & $2(0.8)$ & $2(1.7)$ & $0(0)$ \\
\hline
\end{tabular}

a Significant at $0.001 ;{ }^{\mathrm{b}}$ knowledge is related to participants who are aware about the disorders 

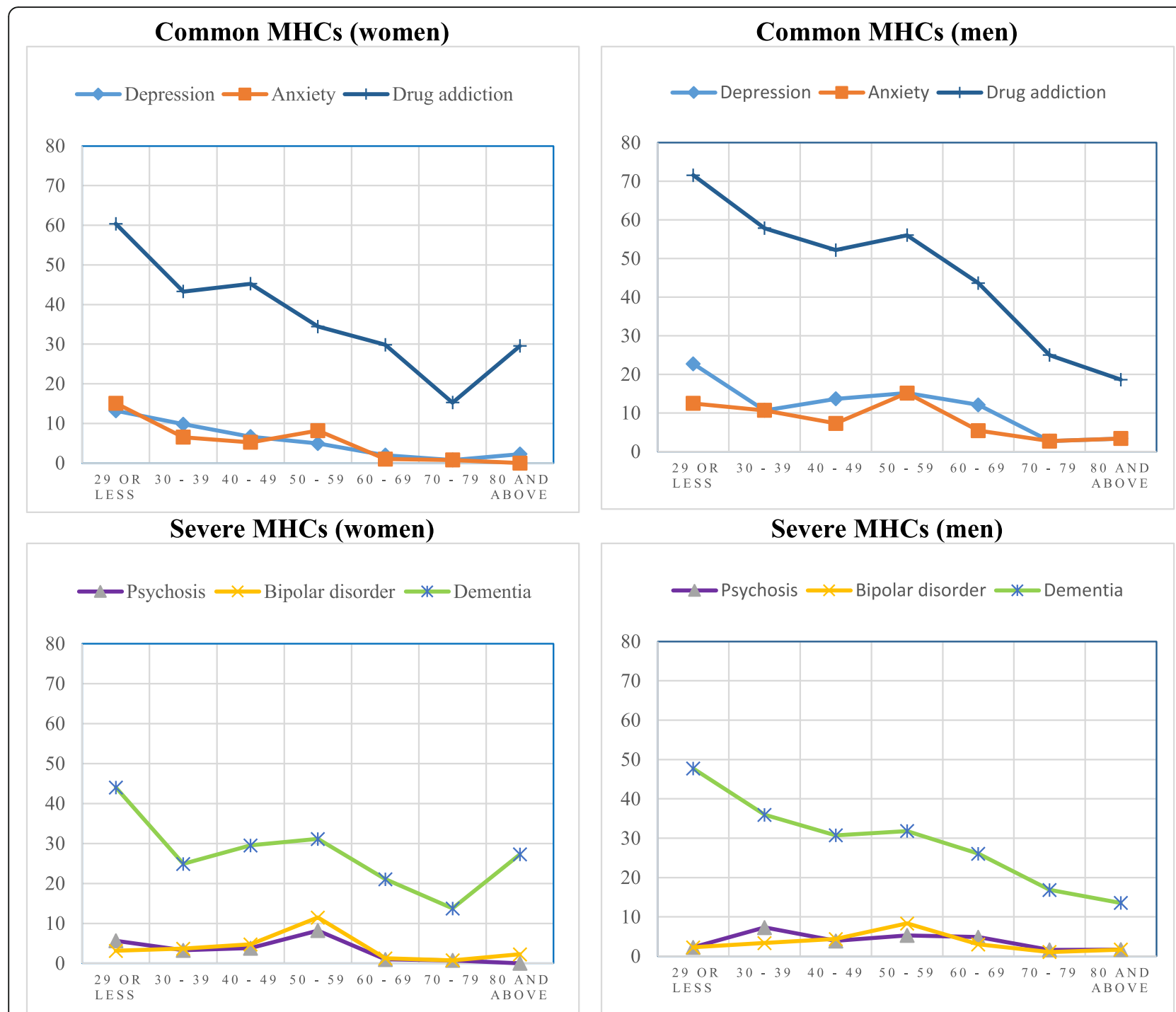

\section{Severe MHCs (men)}

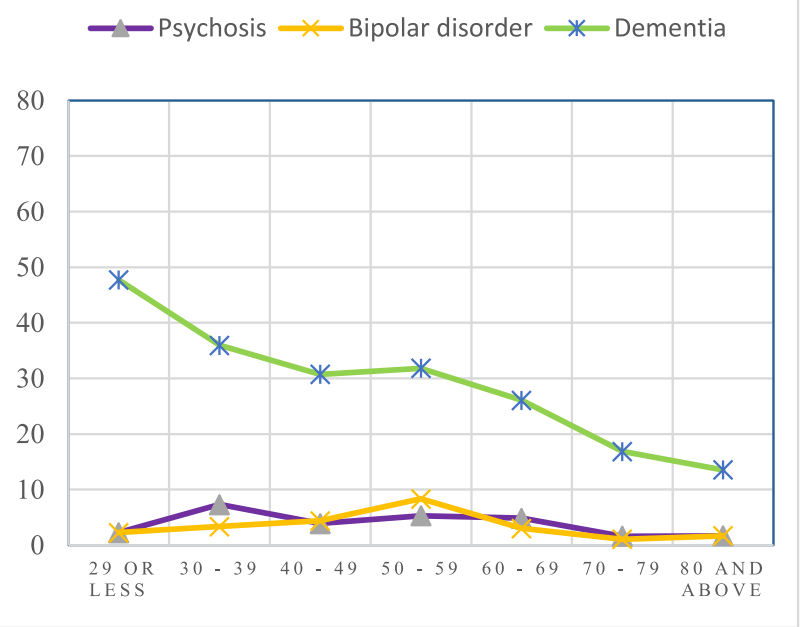

Fig. 1 Percentage of awareness of common and severe mental health conditions in women (left) and men (right) by age group

of education, awareness of common MHCs was $42 \%$ greater in males than in females $(\beta$ (95\% CI): $0.42(0.25$, $0.59)$ ). Age was negatively associated with awareness implying that every increase of 10 years of age was associated with $17 \%$ lower prevalence of awareness ( $\beta$ (95\% $\mathrm{CI}):-0.17(-0.22,-0.12))$, given the other variables in the model. Having at least secondary level of education was associated with $177 \%$ higher prevalence of awareness compared to people with no education or primary level of education ( $\beta$ (95\% CI): 1.77 (1.58-1.97)). Availability of sufficient funds most or all of the time contributed $43 \%$ higher prevalence of awareness compared to unstable financial situation (insufficient funds at least some of the time) ( $\beta(95 \% \mathrm{CI}), 0.43(0.26,0.61))$. On the other hand, gender had no significant association with the awareness of severe MHCs. Age was negatively associated with $6 \%$ lower prevalence of the awareness of severe MHCs $(\beta$ (95\% CI): $-0.17(-0.22,-0.12))$. Having at least secondary level of education was associated with $81 \%$ higher prevalence of awareness of severe MHCs compared to people with no education or primary level of education ( $\beta$ (95\% CI): $0.81(0.67-0.95)$ ). Availability of sufficient funds most or all the time contributed to a $43 \%$ higher prevalence of awareness compared to unstable financial situations (insufficient funds at least some of the time) $(\beta(95 \% \mathrm{CI}), 0.25(0.13,0.38))$ (Table 5).

\section{Discussion}

This study was the very first kind that focused on the MHL amongst the general population in a rural district of Bangladesh. The study reported a very limited awareness about all six MHCs in general population; the lowest being $3.3 \%$ of those interviewed were aware of 
Table 4 Level of awareness of mental health disorders by education and socio-economic status in Narail district in Bangladesh

\begin{tabular}{|c|c|c|c|c|c|c|c|c|c|c|}
\hline \multirow{3}{*}{$\begin{array}{l}\text { Mental } \\
\text { Health } \\
\text { Conditions }\end{array}$} & \multirow{3}{*}{$\begin{array}{l}\text { Awareness } \\
\text { (heard of) }\end{array}$} & \multicolumn{5}{|l|}{ Education } & \multicolumn{4}{|c|}{ Socio-economic condition } \\
\hline & & $\begin{array}{l}\text { Primary } \\
(0-5), \\
n=1619\end{array}$ & $\begin{array}{l}\text { Secondary, } \\
n=326\end{array}$ & $\begin{array}{l}\mathrm{SSC} \text { or } \\
\mathrm{HSC} \\
n= \\
385\end{array}$ & $\begin{array}{l}\text { Degree or } \\
\text { equivalent, } \\
n=96\end{array}$ & $\begin{array}{l}{ }^{*} p \text {-value } \\
\text { for trend }\end{array}$ & $\begin{array}{l}\text { In sufficient funds } \\
\text { for at least some of } \\
\text { the time, } n=1147\end{array}$ & Balance, $n=1037$ & $\begin{array}{l}\text { Sufficient } \\
\text { funds most of } \\
\text { the time, } n= \\
242\end{array}$ & $\begin{array}{l}{ }^{*} p- \\
\text { value } \\
\text { for } \\
\text { trend }\end{array}$ \\
\hline & & n (\%) & n (\%) & n (\%) & n (\%) & & n (\%) & n (\%) & n (\%) & \\
\hline \multirow[t]{4}{*}{$\begin{array}{l}\text { Common } \\
\text { MHCs }\end{array}$} & Depression & $17(1.1)$ & $25(7.6)$ & $\begin{array}{l}94 \\
(24.4)\end{array}$ & $70(72.9)$ & $<0.001$ & $33(2.9)$ & $141(13.6)$ & $32(13.3)$ & $\begin{array}{l}< \\
0.001\end{array}$ \\
\hline & Anxiety & $11(0.7)$ & $30(9.2)$ & $\begin{array}{l}63 \\
(16.4)\end{array}$ & $47(49.1)$ & $<0.001$ & $28(2.4)$ & $102(9.8)$ & $21(8.8)$ & $\begin{array}{l}< \\
0.001\end{array}$ \\
\hline & $\begin{array}{l}\text { Drug } \\
\text { addiction }\end{array}$ & $\begin{array}{l}485 \\
(30.2)\end{array}$ & $123(37.6)$ & $\begin{array}{l}320 \\
(83.3)\end{array}$ & $90(93.8)$ & $<0.001$ & $381(33.2)$ & $478(46.1)$ & $159(66.3)$ & $\begin{array}{l}< \\
0.001\end{array}$ \\
\hline & $\begin{array}{l}\text { Awareness } \\
\text { of any } \\
\text { MHCs }\end{array}$ & $\begin{array}{l}487 \\
(30.1)\end{array}$ & $126(38.5)$ & $\begin{array}{l}326 \\
(84.7)\end{array}$ & $91(94.8)$ & $<0.001$ & $383(33.4)$ & $485(46.8)$ & $162(67.5)$ & $\begin{array}{l}< \\
0.001\end{array}$ \\
\hline \multirow[t]{4}{*}{$\begin{array}{l}\text { Severe } \\
\text { MHCs }\end{array}$} & Psychosis & $14(0.9)$ & $12(3.7)$ & $\begin{array}{l}27 \\
(7.0)\end{array}$ & $32(33.3)$ & $<0.001$ & $15(1.3)$ & $48(4.6)$ & $22(9.2)$ & $\begin{array}{l}< \\
0.001\end{array}$ \\
\hline & Dementia & $\begin{array}{l}314 \\
(19.4)\end{array}$ & $60(18.3)$ & $\begin{array}{l}211 \\
(58.4)\end{array}$ & $77(80.2)$ & $<0.001$ & $234(20.4)$ & $313(30.2)$ & $115(47.9)$ & $\begin{array}{l}< \\
0.001\end{array}$ \\
\hline & $\begin{array}{l}\text { Bipolar } \\
\text { disorder }\end{array}$ & $18(1.1)$ & $8(2.4)$ & $\begin{array}{l}30 \\
(7.8)\end{array}$ & $23(24.2)$ & $<0.001$ & $23(2.0)$ & $31(3.0)$ & $25(10.4)$ & $\begin{array}{l}< \\
0.001\end{array}$ \\
\hline & $\begin{array}{l}\text { Awareness } \\
\text { of any } \\
\text { MHCs }\end{array}$ & $\begin{array}{l}317 \\
(19.6)\end{array}$ & $67(20.5)$ & $\begin{array}{l}216 \\
(56.1)\end{array}$ & $82(85.4)$ & $<0.001$ & $240(20.9)$ & $323(31.1)$ & $119(49.6)$ & $\begin{array}{l}< \\
0.001\end{array}$ \\
\hline \multirow{3}{*}{$\begin{array}{l}\text { Mental } \\
\text { Health } \\
\text { Conditions }\end{array}$} & \multirow{3}{*}{$\begin{array}{l}\text { Awareness } \\
\text { (heard of) }\end{array}$} & \multicolumn{9}{|c|}{ Occupation } \\
\hline & & $\begin{array}{l}\text { Student, } \\
n=45\end{array}$ & $\begin{array}{l}\text { Housewives, } \\
n=978\end{array}$ & \multirow{2}{*}{\multicolumn{2}{|c|}{$\begin{array}{l}\text { Land owner, } n= \\
217\end{array}$}} & $\begin{array}{l}\text { Labourers, } \\
n=282\end{array}$ & Business, $n=218$ & $\begin{array}{l}\text { Government / } \\
\text { non-government } \\
\text { employee, } n= \\
137\end{array}$ & $\begin{array}{l}\text { Retired or } \\
\text { unable to } \\
\text { work, } n=535\end{array}$ & $\begin{array}{l}{ }^{* * p} p- \\
\text { value }\end{array}$ \\
\hline & & n (\%) & n (\%) & & & n (\%) & n (\%) & n (\%) & n (\%) & \\
\hline \multirow[t]{4}{*}{$\begin{array}{l}\text { Common } \\
\text { MHCs }\end{array}$} & Depression & $\begin{array}{l}17 \\
(37.8)^{c}\end{array}$ & $51(5.3)^{\mathrm{a}}$ & \multicolumn{2}{|c|}{$13(6.0)^{\mathrm{a}}$} & $9(3.0)^{\mathrm{a}}$ & $29(13.1)^{b}$ & $60(43.8)^{d}$ & $27(5.0)^{a}$ & $\begin{array}{l}< \\
0.001\end{array}$ \\
\hline & Anxiety & $\begin{array}{l}12 \\
(26.7)^{b}\end{array}$ & $44(4.5)^{a}$ & \multicolumn{2}{|c|}{$11(5.1)^{\mathrm{a}}$} & $10(3.4)^{a}$ & $20(9.0)^{a}$ & $40(29.2)^{c}$ & $14(2.6)^{a}$ & $\begin{array}{l}< \\
0.001\end{array}$ \\
\hline & $\begin{array}{l}\text { Drug } \\
\text { addiction }\end{array}$ & $\begin{array}{l}31 \\
(68.9)^{d}\end{array}$ & $395(40.7)^{b}$ & \multicolumn{2}{|c|}{$114(52.5)^{c}$} & $106(35.7)^{b}$ & $138(62.2)^{c}$ & $106(77.4)^{d}$ & $128(23.8)^{a}$ & $\begin{array}{l}< \\
0.001\end{array}$ \\
\hline & $\begin{array}{l}\text { Awareness } \\
\text { of any } \\
\text { MHCs }\end{array}$ & $\begin{array}{l}31 \\
(68.9)^{c}\end{array}$ & $398(41.0)^{b}$ & \multicolumn{2}{|c|}{$115(53.0)^{b}$} & $106(35.7)^{b}$ & $139(62.6)^{c}$ & $111(81.0)^{d}$ & $130(24.2)^{a}$ & $\begin{array}{l}< \\
0.001\end{array}$ \\
\hline \multirow[t]{4}{*}{$\begin{array}{l}\text { Severe } \\
\text { MHCs }\end{array}$} & Psychosis & $3(6.7)^{a}$ & $24(2.5)^{\mathrm{a}}$ & \multicolumn{2}{|l|}{$4(1.8)^{a}$} & $5(1.7)^{\mathrm{a}}$ & $10(4.5)^{a}$ & $28(20.4)^{b}$ & $11(2.0)^{a}$ & $\begin{array}{l}< \\
0.001\end{array}$ \\
\hline & Dementia & $\begin{array}{l}21 \\
(46.7)^{d}\end{array}$ & $264(27.2)^{b}$ & \multicolumn{2}{|c|}{$71(32.7)^{c}$} & $65(21.9)^{b}$ & $83(37.4)^{c}$ & $84(61.3)^{d}$ & $74(13.8)^{a}$ & $\begin{array}{l}< \\
0.001\end{array}$ \\
\hline & $\begin{array}{l}\text { Bipolar } \\
\text { disorder }\end{array}$ & $4(8.9)^{b}$ & $27(2.8)^{a}$ & \multicolumn{2}{|l|}{$8(3.7)^{a}$} & $2(0.7)^{a}$ & $8(3.6)^{a}$ & $21(15.3)^{b}$ & $9(1.7)^{\mathrm{a}}$ & $\begin{array}{l}< \\
0.001\end{array}$ \\
\hline & $\begin{array}{l}\text { Awareness } \\
\text { of any } \\
\text { MHCs }\end{array}$ & $\begin{array}{l}21 \\
(46.7)^{c}\end{array}$ & $269(27.7)^{b}$ & \multicolumn{2}{|c|}{$73(33.6)^{b}$} & $66(22.2)^{a}$ & $87(39.2)^{c}$ & $89(65.0)^{d}$ & $77(14.3)^{a}$ & $\begin{array}{l}< \\
0.001\end{array}$ \\
\hline
\end{tabular}

Same symbol means there is no significant difference between the occupation and different symbol means significant difference

**indicates Fisher's exact test was used to report $p$ values for multiple pairwise comparisons

${ }^{*} p$-value for trend indicates linear-by-linear association between awareness and underlying ordinal variables (education, socio-economic conditions)

bipolar disorder and the highest being $42 \%$ were aware about drug addiction. More than $50 \%$ of people were not aware of any of the MHCs, whereas less than $1 \%$ people were aware of all the MHCs. Factors associated with lower awareness of MHCs were older age, female gender, lower level of education, lower level of SES, occupations of labourers or housewives. However, irrespective of age, gender, level of education or SES, most of the 
Table 5 Influence of socio-demographic characteristics on the transformed latent trait (person measure of awareness) of MHCs

\begin{tabular}{|c|c|c|c|c|}
\hline \multirow[t]{3}{*}{ Sociodemographic characteristic } & \multicolumn{2}{|l|}{ Common MHCs } & \multicolumn{2}{|l|}{ Severe MHCs } \\
\hline & \multicolumn{2}{|l|}{$\mathrm{N}=2425$} & \multicolumn{2}{|l|}{$\mathrm{N}=2425$} \\
\hline & $\overline{\beta(95 \% \mathrm{Cl})^{a}}$ & $\beta(95 \% \mathrm{Cl})^{b}$ & $\overline{\beta(95 \% \mathrm{Cl})^{a}}$ & $\beta(95 \% \mathrm{Cl})^{b}$ \\
\hline Gender (men vs. women) & $0.51(0.33-0.70)^{c}$ & $0.42(0.25-0.59)^{c}$ & $0.11(-0.01-0.24)$ & $0.06(-0.06-0.18)$ \\
\hline Age per 10-year increase & $-0.33(-0.38--0.28)^{c}$ & $-0.17(-0.22--0.12)^{c}$ & $-0.14(-0.18--0.10)^{\mathrm{c}}$ & $-0.06(-0.1--0.03)$ \\
\hline SES (ref.: at least sometimes insufficient fund) & $1.0(0.82-1.18)^{c}$ & $0.43(0.26-0.61)^{c}$ & $0.5(0.38-0.63)^{c}$ & $0.25(0.13-0.38)^{c}$ \\
\hline Education (ref.: up to primary level of education) & $2.16(1.98-2.34)^{c}$ & $1.77(1.58-1.97)^{c}$ & $0.97(0.85-1.10)^{c}$ & $0.81(0.67-0.95)^{c}$ \\
\hline
\end{tabular}

${ }^{a}$ Unadjusted $\beta(95 \% \mathrm{Cl}) ;{ }^{\mathrm{b}}$ Adjusted $\beta(95 \% \mathrm{Cl})$ for variables in the model; ${ }^{\mathrm{c}}$ Significant at 0.001

participants were able to identify at least one symptom of each of the MHCs items given they were aware of the MHCs, and almost all of them had positive attitudes toward medical or psychological treatments for such conditions.

The association of low level of education and female gender with low awareness of MHCs in this study appeared to align with the findings reported from in India [47]. One of the findings of this study about men being more aware of MHCs than women in both adult and older adult subgroups is quite consistent with that of the study conducted in Qatar [21]. However, another study conducted in Germany reported that the perception of awareness of MHCs among women was higher than men [17]. The disparity of awareness between Bangladeshi women and German women might be due to the fact that women in rural areas in Bangladesh are not sufficiently knowledgeable about the causes of MHCs, not well educated compared to men, do not have sufficient computer literacy, and have limited access to internet or daily newspapers. This study also revealed that education was positively associated with greater awareness of MHCs, which is quite coherent with the findings from other studies [47, 48]. Low SES [49], labourers [50] or housewives [51] were found to be associated with lower level of education, especially in the Asian countries, indicating lower level of education is one of the main barriers of attaining greater awareness of MHCs.

Another barrier in attaining awareness of MHCs can be attributed to the fact of inadequate access to medical facilities in Bangladesh. Bangladesh is the sixth most populous country in the world with approximately 50, 000 medical doctors for 160 million people. Among the medical doctors, less than 1\% (500) are psychiatrists, indicating less than 1 psychiatrist per 300,000 people to provide specialised treatment [52]. This ratio is much lower compared to 126 psychiatrists in Switzerland, and 44 psychiatrists in the United States [53]. For inpatient care, Bangladesh only has one dedicated mental health hospital, and 50 psychiatric units in general hospitals [52]. Such resources are insufficient to provide service for the large population in Bangladesh. The lack of visibility of such services in rural areas may contribute to the poor levels of awareness of MHCs amongst the population living in these areas.

This study provides the first reliable data on the MHL and its associated socio-demographic factors amongst general population in a typical rural district in Bangladesh. The analysis was based on a large data set collected directly through a face-to-face interview from adults and older adults. The sophisticated Rasch analysis technique was applied to quantify the MHCs item responses from a binary scale to a logarithmic scale where the binary scale suffers from identifying the real difference between two binary outcomes.

One of the criticisms of this study could be the measurement of the construct 'socio-economic status'. The subjectivity in reporting availability of funds may affect the appropriateness and validity of socio-economic status. Secondly, the appropriateness of the KAP measure may be questioned because of the single factor/question criterion (where the answer is 'yes' and 'no') in defining the term 'knowledge' and 'Attitude'. Participants were deemed knowledgeable when the participants could identify at least one symptoms of the MHCs given that they were aware of the disorders. Moreover, participants were regarded showing positive attitudes if they who were aware of the MHCs were in favour of taking medical treatment or psychological counselling. It could be argued that questions pertaining to attitudes based on 'yes' and 'no' answers may fail to capture the attitudes towards mental health adequately. Thirdly, this study did not address the potential limitation of this study is its external validity. The findings based on a single-occasion collection of data from a rural district in Bangladesh may not be truly reflective of a national perspective due to differential demographics and level of awareness of MHCs in different parts of the country.

\section{Conclusion}

The level of awareness of MHCs was very low. All participants exhibited positive attitude towards treatments of MHCs given they were aware of the conditions. Females, lower education, older adults, and low SES groups were more likely to have a low level of awareness in most of the MHCs. The study provides evidence- 
based information for planning and implementation of appropriate intervention, especially in high-risk groups such as women and older adults, to increase MHL in rural Bangladesh. Public health programmes should also target those of low socioeconomic status and aim at increasing knowledge of MHCs in rural Bangladesh.

\section{Additional file}

Additional file 1: Associations of socio-demographic characteristics with the combined awareness score of common MHCs items. (DOCX $18 \mathrm{~kb}$ )

\section{Abbreviations}

KAP: Knowledge, attitudes and practice; MHCs: Mental Health Conditions; MHL: Mental health literacy

\section{Acknowledgements}

We particularly acknowledge the contribution of Md Rafiqul Islam, Md Sajibul Islam, Saburan Nesa and Arzan Hosen for their hard work in door-to-door data collection. Finally, we would like to express our gratitude to the study participants for their voluntary participation.

\section{Authors' contributions}

All authors contributed to the conception, design and plan the study. FMA and MNU jointly contributed to data acquisition. MNU analysed the data, drafted the manuscript and interpreted the study findings. FMAl supervised the overall analyses and contributed in preparation of the manuscript. FMA and SB substantially reviewed and revised the manuscript. All authors have read and approved its final version.

\section{Funding}

The Faculty of Health, Arts and Design (FHAD) of the Swinburne University of Technology under the Research and Development Grant Scheme (RDGS) funded data collection for this research project. The funders had no role in the design of the study, data collection or analysis, interpretation of data or writing the manuscript.

\section{Availability of data and materials}

The datasets used and/or analysed during the current study are available from the corresponding author on reasonable request.

\section{Ethics approval and consent to participate}

All procedures performed in studies involving human participants were followed the ethical standards of the institutional and/or national research committee. The study also followed the 1964 Helsinki declaration and its later amendments. The ethics committee of the Swinburne University of Technology Human Ethics Committee (SHR Project 2015/065) has granted the ethical approval. Written informed consent was obtained from all participants included in the study. According to the policy and regulation of the local ethics committee of Bangladesh approval of National Research Ethics Committee (NREC) [54] is not a requirement for research that contributes to academic dissertation/thesis.

\section{Consent for publication}

None applicable.

\section{Competing interests}

The authors declare that they have no competing interests.

\section{Author details}

${ }^{1}$ Department of Statistics, Data Science and Epidemiology; Faculty of Health, Arts and Design, Swinburne University of Technology, Hawthorn, VIC 3122, Australia. ${ }^{2}$ Department of Psychological Sciences; Faculty of Health, Arts and Design, Swinburne University of Technology, Hawthorn, VIC 3122, Australia. ${ }^{3}$ Organisation for Rural Community Development (ORCD), Dariapur, Narail, Bangladesh.
Received: 3 November 2018 Accepted: 31 July 2019

Published online: 13 August 2019

\section{References}

1. Organization, W.H. WHO methods and data sources for global burden of disease estimates 2000-2016. Geneva: WHO Press; 2018.

2. Organization, W.H. World health report: Mental disorders affect one in four people 2001, http://www.who.int/whr/2001/media_centre/press_release/en/ Accessed 5 Dec 2015.

3. Anthony WA, Cohen M, Kennard W. Understanding the current facts and principles of mental health systems planning. Am Psychol. 1990:45(11):1249.

4. Organization, W.H. 10 facts on mental health, 2014, http://www.who.int/ features/factfiles/mental health/mental_health_facts/en/, Accessed 5 Jun 2017.

5. Ferrari AJ, et al. Global variation in the prevalence and incidence of major depressive disorder: a systematic review of the epidemiological literature. Psychol Med. 2013;43(3):471-81.

6. Saxena S, Funk M, Chisholm D. World health assembly adopts comprehensive mental health action plan 2013-2020. Lancet. 2013; 381(9882):1970-1.

7. Jorm AF, et al. "Mental health literacy": a survey of the public's ability to recognise mental disorders and their beliefs about the effectiveness of treatment. Med J Aust. 1997;166(4):182-6.

8. Ndetei DM, et al. Knowledge, attitude and practice (KAP) of mental illness among staff in general medical facilities in Kenya: practice and policy implications. Afr J Psychiatry (Johannesbg). 2011;14(3):225-35.

9. Kilkkinen $\mathrm{A}$, et al. Prevalence of psychological distress, anxiety and depression in rural communities in Australia. Aust J Rural Health. 2007:15(2):114-9.

10. Demaio $A R$, et al. Exploring knowledge, attitudes and practices related to diabetes in Mongolia: a national population-based survey. BMC Public Health. 2013;13:236.

11. Zaman MJ, et al. Socio-economic distribution of cardiovascular risk factors and knowledge in rural India. Int J Epidemiol. 2012;41(5):1302-14.

12. Islam FMA, et al. Factors associated with awareness, attitudes and practices regarding common eye diseases in the general population in a Rural District in Bangladesh: the Bangladesh population-based diabetes and eye study (BPDES). PLoS One. 2015;10(7):1-12.

13. Islam FM, et al. Knowledge, attitudes and practice of diabetes in rural Bangladesh: the Bangladesh population based diabetes and eye study (BPDES). PLoS One. 2014:9(10):1-11.

14. Carels RA, et al. A novel stepped-care approach to weight loss: the role of self-monitoring and health literacy in treatment outcomes. Eat Behav. 2017: 26:76-82

15. Reavley NJ, Jorm AF. Recognition of mental disorders and beliefs about treatment and outcome: findings from an Australian National Survey of mental health literacy and stigma. Aust N Z J Psychiatry. 2011;45(11):947-56

16. Overton SL, Medina SL. The stigma of mental illness. J Couns Dev. 2008; 86(2):143-51.

17. Hillert A. The general public's relationship to the mentally ill as seen by psychiatric research: interactions of motives, methods and results of psychiatric attitude-research. Nervenheilkunde. 1999:18(4):191-6.

18. Regier DA, et al. The Nimh depression awareness, recognition, and treatment program - structure, aims, and scientific basis. Am J Psychiatr. 1988;145(11):1351-7.

19. Lauber C, Rossler W. Stigma towards people with mental illness in developing countries in Asia. Int Rev Psychiatry. 2007;19(2):157-78.

20. Gureje O, et al. Community study of knowledge of and attitude to mental illness in Nigeria. Br J Psychiatry. 2005;186:436-41.

21. Bener A, Ghuloum S. Gender differences in the knowledge, attitude and practice towards mental health illness in a rapidly developing Arab society. Int J Soc Psychiatry. 2011:57(5):480-6.

22. Avasthi A. Indianizing psychiatry-is there a case enough? Indian J Psychiatry. 2011;53(2):111

23. Almanzar S, et al. Knowledge of and Attitudes Toward Clinical Depression Among Health Providers in Gujarat, India. Ann Global Health. 2014;80(2):89-95.

24. Khaleque A, Wadud N, Chowdhury M. Work attitudes, strain and mentalhealth of employed mothers in Bangladesh. Work Stress. 1988;2(1):41-7.

25. Choudhury WA, Quraishi FA, Haque Z. Mental health and psychosocial aspects of disaster preparedness in Bangladesh. Int Rev Psychiatry. 2006; 18(6):529-35.

26. Izutsu T, et al. Mental health, quality of life, and nutritional status of adolescents in Dhaka, Bangladesh: comparison between an urban slum and a non-slum area. Soc Sci Med. 2006;63(6):1477-88. 
27. Hashima-E N, et al. Marital relationship is a major contributory factor for antepartum depression and anxiety: evidence from rural Bangladesh. J Psychosom Obstet Gynecol. 2010;31:60.

28. Mollik MAH. Mental health problems treated with medicinal plants by the Khyang of Chittagong Hill tracts within Bangladesh: from bench to bedside. J Neuroimmunol. 2014;275(1-2):224.

29. Nahar N, et al. Increasing the provision of mental health care for vulnerable, disaster-affected people in Bangladesh. BMC Public Health. 2014;14:1880-80.

30. Hengartner MP, et al. Mental health and Functioning of Female sex Workers in chittagong, Bangladesh. Front Psychiatry. 2015;6:1-7.

31. Hoque R. Major Mental Health Problems of Undergraduate Students in a Private University of Dhaka, Bangladesh. Eur Psychiatry. 2015;30. p 1880-1880.

32. Uddin MN, Islam FMA, Al Mahmud A. Psychometric evaluation of an interviewadministered version of the Kessler 10-item questionnaire (K10) for measuring psychological distress in rural Bangladesh. BMJ Open. 2018:8(6):1-11.

33. Statistics, B.B.o. Population and Housing Census 2011, http://www.bbs.gov.bd/ site/page/47856ad0-7e1c-4aab-bd78-892733bc06eb/-, Accessed 15 Mar 2017.

34. Statistics, B.B.o. Population \& Housing Census 2011 (Zila Series \& Community Series) http://203.112.218.65:8008/WebTestApplication/userfiles/ Image/PopCen2011/C_Narail.pdf, Accessed 1 Feb 2017.

35. Agency, C.I. Adult literacy Rate in Bangladesh, 2015, https:/www.cia.gov/ library/publications/the-world-factbook/geos/bg.html, Accessed, 2 Jun 2017.

36. Data.gov.bd Current marital status of population by different age group 2012, http://data.gov.bd/dataset/current-marital-status-population-differentage-group-2012, Accessed 8 Apr 2017.

37. Ministry of Finance, T.P.R.o.B. Socio-Economic Indicators of Bangladesh, 2017, https://mof.portal.gov.bd/site/page/28ba57f5-59ff-4426-970abf014242179e/Bangladesh-Economic-Review, Accessed 8 June 2017

38. Uddin MN, et al. Psychological distress and quality of life: rationale and protocol of a prospective cohort study in a rural district in Bangladesh. BMJ Open. 2017;7(9):1-10.

39. Uddin MN, Islam FMA. Psychometric evaluation of an interviewadministered version of the WHOQOL-BREF questionnaire for use in a crosssectional study of a rural district in Bangladesh: an application of Rasch analysis. BMC Health Serv Res. 2019;19(1):216.

40. Hossain MD, et al. Mental disorders in Bangladesh: a systematic review. BMC Psychiatry. 2014;14:216.

41. Reavley NJ, Jorm AF. National survey of mental health literacy and stigma. Canberra: Department of Health and Ageing; 2011.

42. Cheng YH, et al. Self-rated economic condition and the health of elderly persons in Hong Kong. Soc Sci Med. 2002;55(8):1415-24.

43. Andrich D. Probabilistic Models for Some Intelligence and Attainment Tests (Expanded Edition) - Rasch,G. Appl Psychol Meas. 1981;5(4):545-50.

44. Rasch $\mathrm{G}$. An item analysis which takes individual differences into account. Br J Math Stat Psychol. 1966;19:49-57.

45. RUMM2030, RUMM2030 For analysing assessment and attitude questionnaire data. 2017

46. IBM Corp. Released 2015. IBM SPSS statistics for windows, version 24.0 Armonk, NY: IBM Corp; 2017

47. Patel V, Kleinman A. Poverty and common mental disorders in developing countries. Bull World Health Organ. 2003:81(8):609-15.

48. Ortiz-Hernandez L, Lopez-Moreno S, Borges G. Socioeconomic inequality and mental health: a Latin American literature review. Cadernos De Saude Publica. 2007;23(6):1255-72.

49. Association, A.P. Education and Socioeconomic Status, 2016, https://www.apa org/pi/ses/resources/publications/factsheet-education.pdf, Accessed 8 Mar 2017.

50. Leonard JH, et al. Risk of mental health disorders among farmers involved in palm plantation occupation. Clin Ter. 2013;164(5):403-6.

51. Ali TS, et al. Gender roles and their influence on life prospects for women in urban Karachi, Pakistan: a qualitative study. Glob Health Action. 2011:4:1-10.

52. Organization, W.H. Mental Health Atlas Bangladesh Country Profile 2014, http://www.who.int/mental_health/evidence/atlas/profiles-2014/bgd. pdf?ua=1, Accessed 16 Feb 2017.

53. Organization, W.H. Mental Health Atlas 2014, https://apps.who.int/iris/ bitstream/handle/10665/178879/9789241565011_eng.pdf;jsessionid=3BF1B1 7934BC28FFE2FC649127AC36D4? sequence=1. Accessed 5 July 2017.

54. NREC, Ethics Committee Approval from Bangladesh. http://www.dghs.gov. bd/images/docs/Notice/Notice_30_07_2017.pdf, Accessed 5 July, 2019.

\section{Publisher's Note}

Springer Nature remains neutral with regard to jurisdictional claims in published maps and institutional affiliations.

\section{Ready to submit your research? Choose BMC and benefit from:}

- fast, convenient online submission

- thorough peer review by experienced researchers in your field

- rapid publication on acceptance

- support for research data, including large and complex data types

- gold Open Access which fosters wider collaboration and increased citations

- maximum visibility for your research: over $100 \mathrm{M}$ website views per year

At BMC, research is always in progress.

Learn more biomedcentral.com/submissions 